\title{
INVESTIGATIONS ON TORSION OF THE TWO-CHORDS SINGLE LACED MEMBERS
}

\author{
Paweł LORKOWSKI ${ }^{1}$, Bronisław GOSOWSKI \\ Wrocław University of Science and Technology, Wrocław, Poland
}

\begin{abstract}
The paper presents experimental and numerical studies to determine the equivalent second moment of area of the uniform torsion of the two-chord steel single laced members. The members are used as poles of railway traction network gates, and steel columns of framed buildings as well. The stiffness of uniform torsion of this kind of columns allows to the determine the critical loads of the spatial stability. The experimental studies have been realized on a single - span members with rotation arrested at their ends, loaded by a torque applied at the mid-span. The relationship between angle of rotation of the considered cross-section and the torque has been determined. Appropriate numerical model was created in the ABAQUS program, based on the finite element method. A very good compatibility has been observed between experimental and numerical studies. The equivalent second moment of area of the uniform torsion for analysed members has been determined by comparing the experimental and analytical results to those obtained from differential equation of non-uniform torsion, based on Vlasov's theory. Additionally, the parametric analyses of similar members subjected to the uniform torsion, for the richer range of cross-sections have been carried out by the means of SOFiSTiK program. The purpose of the latter was determining parametrical formulas for calculation of the second moment of area of uniform torsion.
\end{abstract}

Keywords: steel structure, two-chords member, single laced member, torsion, experimental and numerical investigation

${ }^{1}$ Corresponding author: Wroclaw University of Science and Technology, Faculty of Civil Engineering, Wybrzeże Wyspiańskiego 27, 50-370 Wrocław, Poland, e-mail: pawel.lorkowski@pwr.edu.pl, tel.: +48713203815 


\section{INTRODUCTION}

The considered herein two-chord members found wide application in the building industry, among others, as individual traction columns in tram net (see Figure 1a) [6] or poles of railway traction of network gate (see Figure 1b) [5]. These columns are constructed from two channel chords connected by lacing made of flat bars or angles. Usually in similar way the columns of industrial buildings are designed (see Figure 1c) $[3,12,13]$. In the buildings equipped by overhead cranes, the upper part of the stepped columns is made of a double-T members, whereas the lower part is constructed from channels, double-T or hollow profiles, laced by angles inclined of $45^{\circ}$. These types of structural solutions are also used in the United States of America [18].
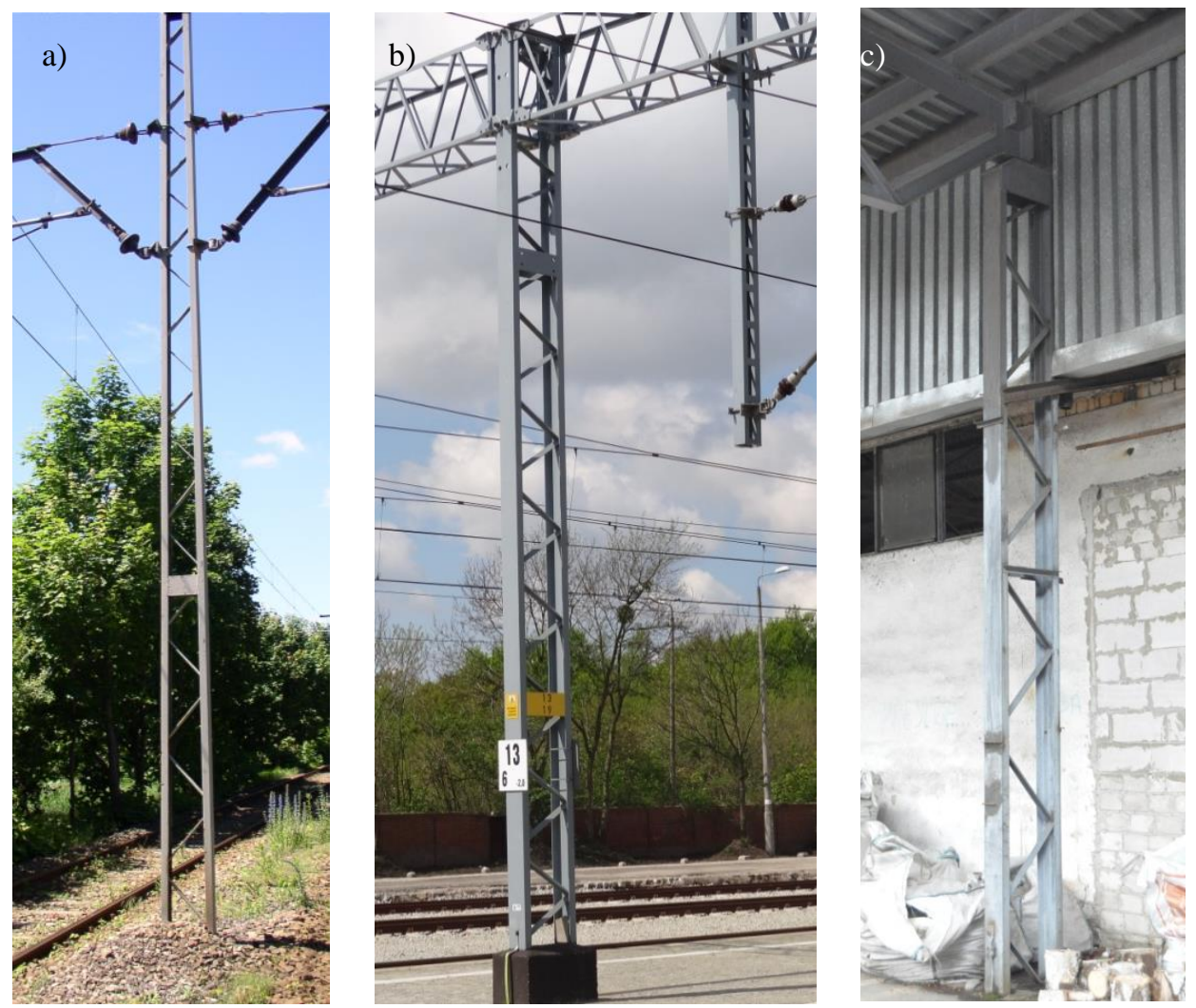

Fig. 1. Examples of investigation columns: a) tram railway support,

b) intermediate column in railway traction gate, $\mathrm{c}$ ) in industrial building

As a part of doctoral thesis [14] the experimental investigations in semi-technic scale have been conducted for elements with the construction corresponding to that used for columns in railway traction gates or columns supporting the tram 
traction network. These results have been compared to the theoretical ones obtained for numerical models created by a program based on finite elements method.

The purpose of the research was to determine the rigidity to torsion of the described above elements, but first of all the second moment of area of uniform torsion $I_{\bar{T}}$ and warping torsion section constant $I_{\bar{\omega}}$ have been studied. These characteristics are strictly necessary to determine the critical resistance of the elements sensitive to the spatial form of instability namely: in case of elements subjected to unaxial compression - the critical load of flexural-torsional buckling, in case of elements under bending - the critical moment of lateral buckling. The sensitive to spatial form of instability of these type elements was considered in master thesis [11].

\section{DESCRIPTION OF TEST PIECES AND TEST STAND FOR PHYSICAL MODELS}

Two types of members with different lacing have been tested. In all types the chords have been made of hot-rolled channels 80, spaced $221 \mathrm{~mm}$ (see Figure 2). Lacings have been used in the form of square hollow section RQ $40 \times 3 \mathrm{~mm}$ or flat bars FB $40 \times 5 \mathrm{~mm}$. In the majority of elements the diagonals have been arranged at an angle $45^{\circ}$ with the respect to the chords.

Figure 2a). shows the model S-1 with the lacing made of rectangular hollow sections, whereas model S-2 (see Figure 2 b) has been laced by flat bars.

a)

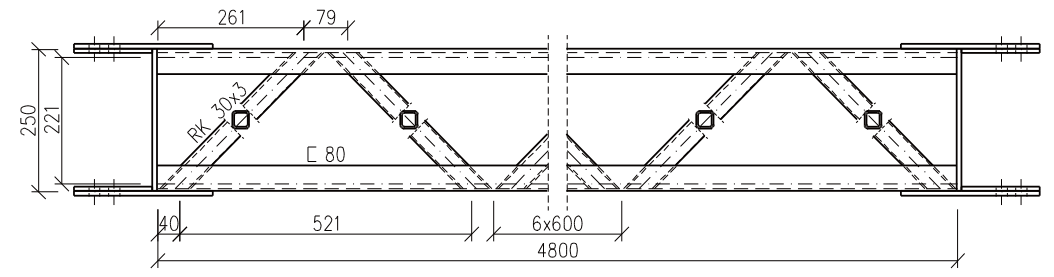

b)

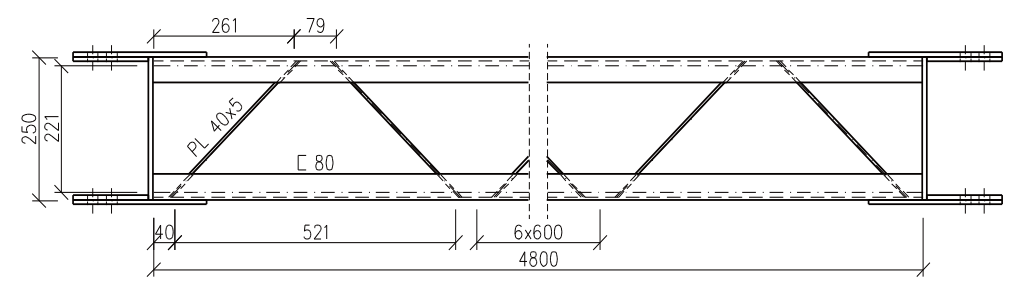

Fig. 2. Geometry of the models: a) S-1, b) S-2

The tests to torsion have been carried out on two models of every type.

The chords of all tested elements have been made of the steel grade S355, whereas for lacings steel S235 have been used. 
The models of considered two-chord elements with a scheme shown in Figure 3 have been subjected to the non-uniform torsion on a specially arranged stand (see Figure 4). The load has been exerted by a torque applied in the mid-span. The ends of the member have been arrested due to torsion. The distance between bearings was $4.555 \mathrm{~m}$.

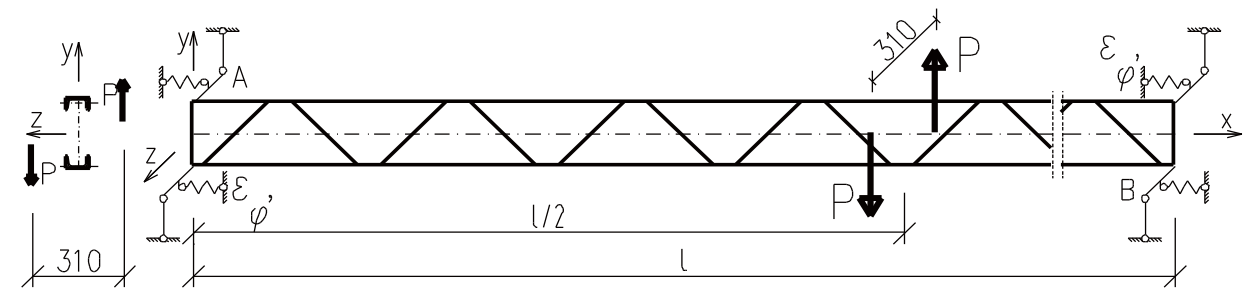

Fig. 3. Scheme of the two-chord member under non-uniform torsion

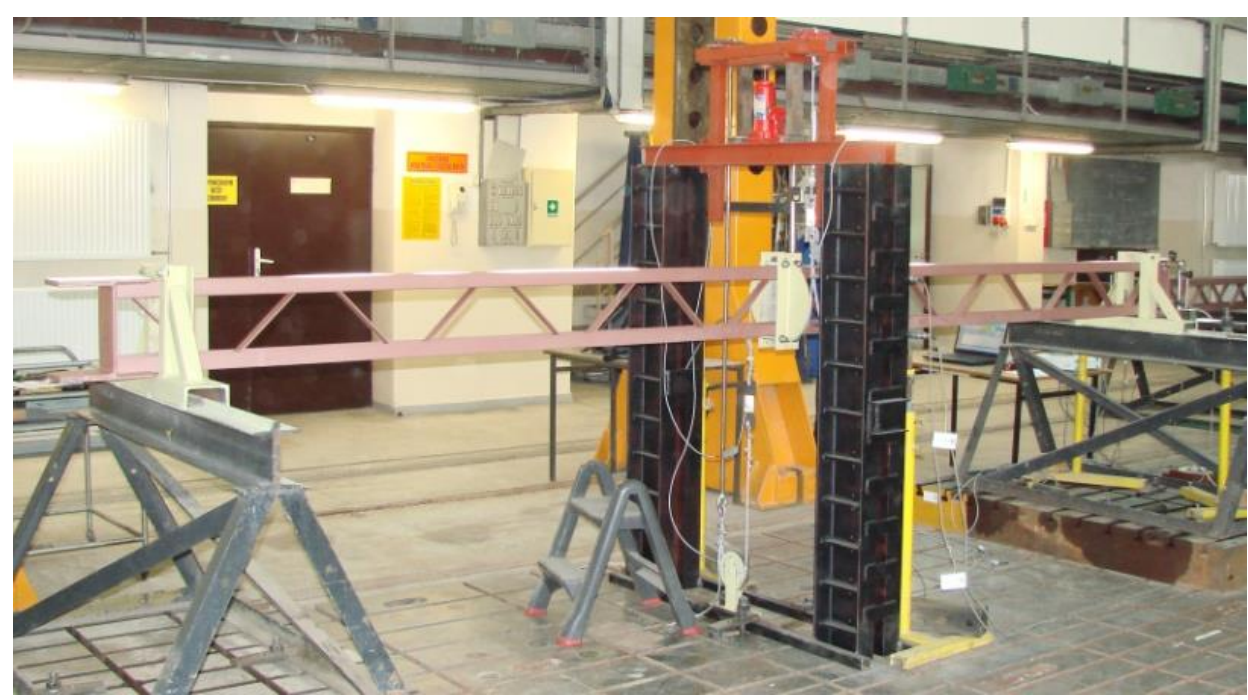

Fig. 4. Model of type $\mathrm{S}$ on the test stand designed for torsion

The torque $M_{s}$ has been realized by twisting couple of forces $P, 310 \mathrm{~mm}$ spaced (see Figure 5). The load $P$ has been reached by a hydraulic jack having a maximum load-capacity of $100 \mathrm{kN}$.

Individual loads $P$ have been recorded by especially constructed and calibrated set of dynamometers based on electro-resisting gauges. The value of $P$ has been recorded electronically every $1 \mathrm{sec}$.

The basic quantity to be measured in the studies was the angle $\varphi$ of torsion of the mid-span cross-section of a member. This has been accomplished by means of 
two couples of inductive gauges attached perpendicularly to the main axis, vertically and horizontally, respectively (Figure 6a).

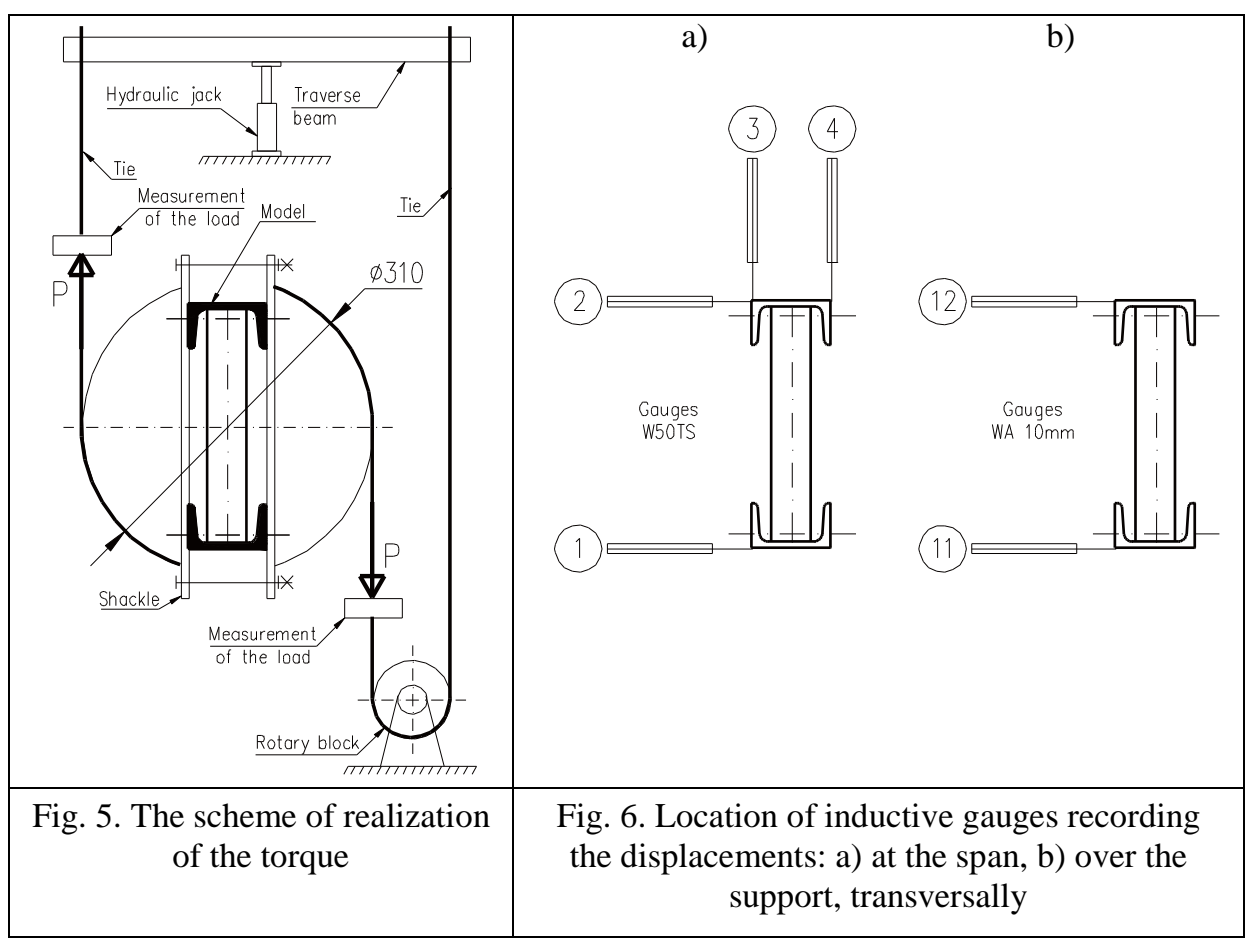

Additionally, the rigidity of the support $\mathrm{A}$ has been recorded by means of two gauges placed horizontally (Figure 6b).

\section{THE COURSE OF EXPERIMENTAL INVESTIGATIONS}

All test models have been indicated before the investigations, i.e.: dimensions of the profiles, the gauges (transverse and longitudinal) of the built-up member and its geometrical imperfection. In the first model to be tested, the dimensions have been checked in five random cross-sections, which has been limited to three crosssections in the rest of models. Since the dimensional deviations from the nominal values have been considered as acceptable by standards $[18,20]$, the further analysis has been based on designing dimensions of elements and nominal dimensions of profiles $[2,4]$.

The models have been subjected to torsion in three steps of load-unload cycle with a growing torque. The load of S-models have been adjusted to values that are not causing any permanent strains due to the planned further tests. 
In Table 1 the test results for a model S-1.1 have been listed. For each cycle the both maximum value of torque $M_{s}$, and the permanent strain (remaining angle of torsion) after unloading have been given.

Table 1. Listed test results of the angle of torsion at the mid-span of the model S-1

\begin{tabular}{|c|c|c|c|c|}
\hline \multirow{14}{*}{ 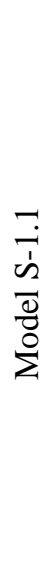 } & \multirow{3}{*}{ Cycle } & \multirow{3}{*}{ Torque } & \multicolumn{2}{|c|}{ Experimental results } \\
\hline & & & & sion \\
\hline & & & Current & Remaining \\
\hline & - & $\mathrm{kNm}$ & $\mathrm{rad}$ & $\mathrm{rad}$ \\
\hline & \multirow{3}{*}{1} & 0.500 & 0.0247 & \multirow{3}{*}{0.0008} \\
\hline & & 1.000 & 0.0506 & \\
\hline & & 1.547 & 0.0783 & \\
\hline & \multirow{3}{*}{2} & 1.000 & 0.0509 & \multirow{3}{*}{0.0017} \\
\hline & & 2.000 & 0.1020 & \\
\hline & & 2.177 & 0.1116 & \\
\hline & \multirow{4}{*}{3} & 1.000 & 0.0525 & \multirow{4}{*}{0.0043} \\
\hline & & 2.000 & 0.1029 & \\
\hline & & 2.750 & 0.1426 & \\
\hline & & 2.794 & 0.1455 & \\
\hline
\end{tabular}

The rest of models have been investigated analogously.

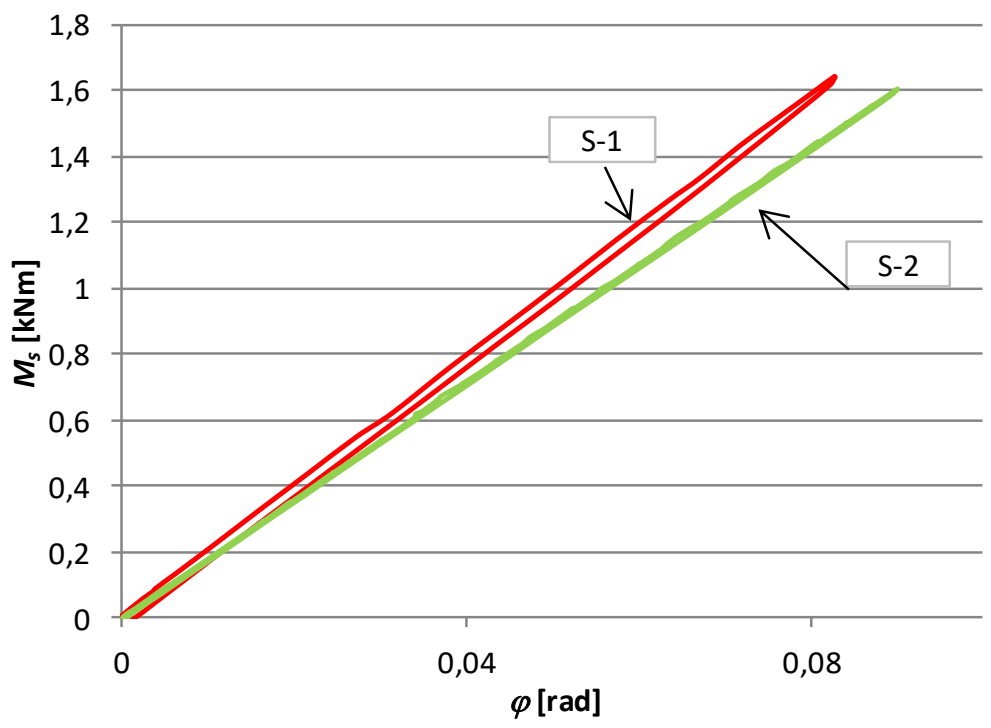

Fig. 7. Relationship load-angle of torsion for tested models

The load-displacement relationship has been introduced (Figure 7) for the torque $M_{s}$ and corresponding angle of torsion $\varphi$ during the first cycle of the load test. The maximum rigidity to torsion has been presented by the model S-1. 


\section{ANALYSIS OF TEST RESULTS OF THE PHYSICAL MODELS}

The differential equation of the torsional angles for a member under non-uniform torsion (see Figure 3), that fulfils the condition $0 \leq x \leq l / 2$ is written as $[8,9]$ :

$$
E I_{\omega} \cdot \varphi^{(4)}(x)-G I_{T} \cdot \varphi^{(2)}(x)=0
$$

The general solution of equation (4.1) takes a form:

$$
\varphi(x)=C_{1}+C_{2} x+C_{3} \frac{1}{k^{2}}(\cosh k x-1)+C_{4} \frac{1}{k^{3}}(\sinh k x-k x),
$$

where: $C_{1}, C_{2}, C_{3}, C_{4}-$ constants of integration, $k=\sqrt{G I_{T} /\left(E I_{\omega}\right)}$.

For a member having a scheme as shown in Figure 3 the boundary condition takes a form:

$$
\varphi(0)=\varphi^{(2)}(0)=0, \varphi^{(1)}\left(\frac{l}{2}\right)=0, M\left(\frac{l}{2}\right)=\frac{M_{s}}{2} .
$$

From the general solution (4.2), after determining the constants of integration from the boundary conditions (4.3), one may obtain a general relationship for the angle of torsion:

$$
\varphi(x)=\frac{M_{S}}{2 k^{3} E I_{\omega}}\left(k x-\frac{\sinh k x}{\cosh \frac{k l}{2}}\right) .
$$

The equivalent warping torsion section constant of the two-chord member [14, 17], built-up of two parallel chords and one plane lacing, is determined on the base of geometrical characteristics of the chords:

$$
I_{\bar{\omega}}=2\left(I_{\omega c h}+a^{2} \cdot I_{y c h}\right),
$$

where: $a$-distance between the shear centre and the centroid of the built-up crosssection, $I_{y c h}, I_{\omega c h}-$ second moment of area about $y$ axis, warping torsion section constant of a single chord, respectively [14, 17] (in the work [16], in the equation like (4.5), the distance $a$ is defined incorrectly).

For models S-1, S-2, the mean value of the angle of torsion and warping have been calculated for the level of loading by torque $M_{s}$ equal to: 1.0, 2.0, 2.75 $[\mathrm{kNm}]$, where the cycle of loading has been taken into account only as this appearing first. 
On the basis of received results of the angle of torsion for the elements S-1, S-2, having $I_{\bar{\omega}}$ determined from equation (4.5), the equivalent $I_{\bar{T}}$ has been iteratively searched employing the formula (4.4). Table 2 presents the results of comparison.

Table 2. The list of results for models S-1, S-2, and the equivalent second moment of area $I_{\bar{T}}$

\begin{tabular}{|c|c|c|c|c|}
\hline \multirow{3}{*}{ Model } & $l$ & Torque & Angle of torsion & $I_{\bar{T}}$ \\
\cline { 3 - 5 } & $\mathrm{m}$ & $\mathrm{kNm}$ & $\mathrm{rad}$ & $\mathrm{cm}^{4}$ \\
\hline \multirow{3}{*}{$\mathrm{S}-1$} & \multirow{3}{*}{4.555} & 1.000 & 0.0512 & 19.123 \\
\cline { 4 - 5 } & & 2.000 & 0.1019 & 19.221 \\
\cline { 4 - 5 } & & 2.750 & 0.1426 & 18.777 \\
\cline { 3 - 5 } $\mathrm{S}-2$ & 1.000 & 0.0564 & 16.786 \\
\cline { 3 - 5 } & & 2.000 & 0.1135 & 16.667 \\
\cline { 3 - 5 } & & 2.750 & 0.1581 & 16.359 \\
\hline
\end{tabular}

A good agreement between the second moment of area of the uniform torsion (see Table 2) for any level of loading, confirms the correctness of the assumed theoretical model. The more extensive program of this type has been presented in [15].

\section{STUDIES ON NUMERICAL MODELS IN ABAQUS PROGRAM}

Studies on numerical models have been carried out using the computer program ABAQUS [1], created on the basis of finite elements method (FEM).

The calculations by ABAQUS program have been performed using the resources made available by the Wrocław Centre for Networking and Supercomputing (http://wcss.pl) under the grant No 306.

Models have been generated in the CAE module, while calculations have been executed in the STANDARD module. The models have been divided to 20-nodal solid finite elements (see Figure 8) with a reduced integration (C3D20R), but in some places, where the model's geometry would not allow it, 15-nodal solid elements (C3D15) have been assumed. The solid elements, in the contrary to shell elements, are able to consider the strains throughout the thickness of the crosssection and therefore this shape of elements has been used herein [10]. The sizes of finite elements have been chosen so that the maximum of them does not exceed $10 \mathrm{~mm}$ in any of thousands (depending of the model's type) of existing elements. 


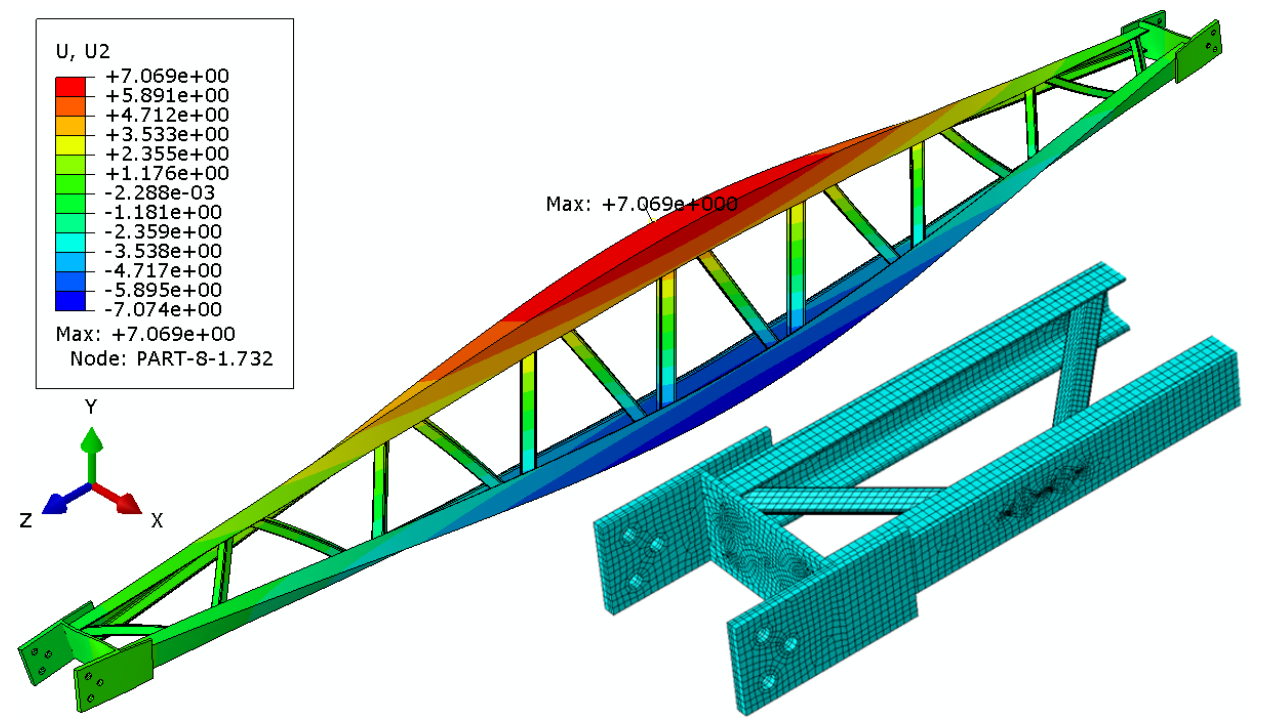

Fig. 8. The map of displacements for a model S-1 in Y-direction (enlarged 40 times) and meshing scheme

The material characteristics have been assumed like for physical models, and the linear-elastic model has been assumed.

The static scheme and the way of load application have been similar to that taken for physical models. Due to the linear-elastic range of the strength analysis, the load has been applied only one time as a torque $M_{s}=1 \mathrm{kNm}$, in the contrary to physical models incrementally loaded in three cycles.

The angle of torsion of the mid-span cross-section (see Figure 8) have been examined like in the case of physical models.

In Table 3, the results of calculations of the angle of torsion in the middle of the span have been summarized. Employing the formula (4.5) $I_{\bar{T}}$ has been iteratively determined and substituted to the equation (4.4).

Table 3. Results of analysis of models $\mathrm{S}$

\begin{tabular}{|l|c|c|c|c|}
\hline \multirow{2}{*}{ Model } & $l$ & $M_{s}$ & Angle of torsion & $I_{\bar{T}}$ \\
\cline { 2 - 5 } & $\mathrm{m}$ & $\mathrm{kNm}$ & $\mathrm{rad}$ & $\mathrm{cm}^{4}$ \\
\hline $\mathrm{S}-1$ & \multirow{2}{*}{4.555} & \multirow{2}{*}{1.0} & 0.05655 & 16.69 \\
\cline { 4 - 5 } $\mathrm{S}-2$ & & 0.06401 & 14.09 \\
\hline
\end{tabular}

In models of type $\mathrm{S}$ discrepancies can be caused by two factors. At the ends of a member the gusset plates are modelled, which in fact they have been planned to attached the model to the another test device. So, the first factor results from those plates and the diaphragm at the end the member that reduce undoubtedly the 
warping effect at its end. The second factor may result from the fact that the bearing restraints are not applied precisely at the ends of the member but at a certain distance. The cantilever portion of the chord limits adequately the warping effect as well (see [14, 15]).

Table 4 summarizes the both mean values of the equivalent second moment of area obtained from tests of physical models and corresponding results of numerical analysis.

Table 4. Equivalent second moment of area of the uniform torsion $I_{\bar{T}}$ in $\mathrm{cm}^{4}$

\begin{tabular}{|l|c|c|c|}
\hline Model & Physical models & Numerical models & Relative error \\
\hline S-1 & 19.04 & 16.69 & $12.34 \%$ \\
\hline S-2 & 16.60 & 14.09 & $15.12 \%$ \\
\hline
\end{tabular}

It can be seen (see Table 4) that $I_{\bar{T}}$ determined from physical models is, in the majority of cases, somewhat larger from that obtained for numerical models. Owing to the small difference it can be generally considered that the numerical models used herein allow the safe estimation of the angle of torsion of the studied elements.

\section{PARAMETRIC ANALYSES OF MEMBERS SUBJECTED TO PURE TORSION}

Columns having a similar shape like these shown on Figure 1 of the type S-1 and $\mathrm{S}-2$, but with a wider range of cross-section flanges, diagonals and variable distance between chords have been subjected to numerical studies. The members have been modelled by beam elements with seven degrees of freedom in SOFiSTiK program [21], whereas the action of pure torsion moment $M_{s}=1 \mathrm{kNm}$ have been produced by a couple of forces applied at the ends of beams (see Figure 9). The analysed elements consist of seven segments, built-up of chords with distance $d$ between their centroids and connected by two diagonals. Their weld supported at one side and totally restrained against displacement, but free to warping.

The length of every model has been covered by 7 segments in order to avoid the effect of the support on the angle of torsion. The angle of torsion $\varphi$ is measured in the cross-section $\alpha-\alpha$ that is not affected by the both cantilever ending of the chord and adjacent concentrated forces. 


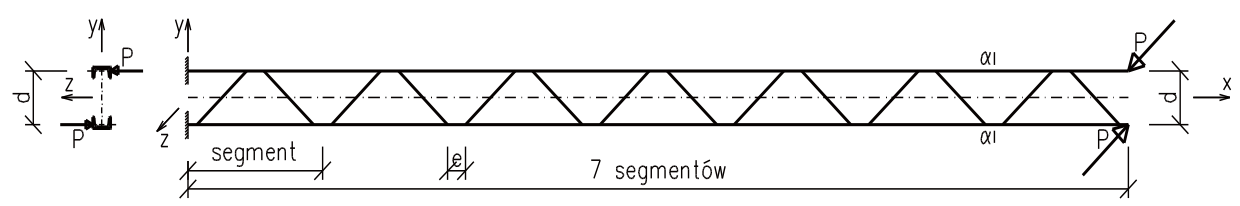

Fig. 9. Scheme of the two-chord member in a uniform torsion

The assortment of products used for modelling of the members subjected to pure torsion is listed in Table 5.

Table 5. Data of the examined models

\begin{tabular}{|c|c|c|}
\hline Chords & Diagonals & Spacing $d[\mathrm{~mm}]$ \\
\hline $\begin{array}{l}\text { C 80, C 100, C120 } \\
\text { IPE 80, IPE 100, IPE } 120 \\
\text { I 80, I 100, I } 120\end{array}$ & $\begin{array}{c}\text { PL } 40 \times 5 \text {, PL } 50 \times 5 \text {, PL } 60 \times 5 \\
\text { PL } 40 \times 8 \text {, PL } 50 \times 8, \text { PL } 60 \times 8 \\
\text { L } 30 \times 3 \text {, L } 40 \times 4 \text { L } 50 \times 5, \text { L } 60 \times 6 \\
\text { RK } 30 \times 3, \text { RK } 40 \times 4, \text { RK } 50 \times 5\end{array}$ & $\begin{array}{l}171,196 \\
221,246 \\
271\end{array}$ \\
\hline
\end{tabular}

The equivalent second moment of area of a pure torsion of examined members in relationship of angle of torsion $\varphi$ is:

$$
I_{\bar{T}}=\frac{M_{s} \cdot l}{G \cdot \varphi} .
$$

On the base of analysis of the individual geometric characteristics of the cross sections of chords and diagonals, the formula has been defined and then subjected to multi-regression by the program STATISTICA [22]. The formula has been developed taking into account the characteristics of chords and diagonals (notation $c h$ and $d i$, respectively) as follows as: cross-sectional area $A$, second moments of area about corresponding axes $I_{y}, I_{z}$, second moment of area for the pure torsion $I_{T}$, and the distance between the centroids of chords $d$. Finding a suitable expressions has been based on the both significance of the parameters and their coincidence. After successive approximations the data having a little impact on the solution have been rejected. The coincidence between $I_{T c h}$ i $I_{y d i}$ has been noted. Finally, after the study of 450 combinations of members, the expression for the equivalent second moment of area of a pure torsion of members with diagonals having an open cross-section is:

$$
I_{\bar{T}}=14.78 \cdot I_{T c h}-25.28 \cdot \frac{I_{T c h}}{I_{y d i}} \ln \left(\frac{I_{y d i}}{\mathrm{~cm}^{4}}\right)-2.27\left[\mathrm{~cm}^{4}\right] .
$$

The expression remains valid for data given in $\mathrm{cm}$ or in derivates.

A similar analysis has been done for members with diagonals of closed crosssection. Examination of 150 combinations allowed to formulate expression (6.3) and like for expression (6.2) the multi-regression has been carried out. 


$$
I_{\bar{T}}=15.68 \cdot I_{T c h}+0.88 \cdot I_{y d i}-11.6 \frac{I_{T c h}}{I_{y d i}} \cdot A_{d i}\left[\mathrm{~cm}^{4}\right] .
$$

Employing expressions (6.2) and (6.3) the equivalent moment $I_{\bar{T}}$ has been calculated. In Table 6 . the comparison of test results, numerical results and those obtained from expression (6.2) and (6.3) has been summarized.

Table 6. Comparison $I_{\bar{T}}$ obtained from tests, numerical analyses, and expression (6.2), (6.3)

\begin{tabular}{|l|l|l|l|}
\hline Member & Physical tests & Numerical tests & Expression (6.2) or (6.3) \\
\hline $\mathrm{S}-1$ & $19,04 \mathrm{~cm}^{4}$ & $16.69 \mathrm{~cm}^{4}$ & $16,03 \mathrm{~cm}^{4}$ \\
\hline $\mathrm{S}-2$ & $16,60 \mathrm{~cm}^{4}$ & $14.09 \mathrm{~cm}^{4}$ & $14,12 \mathrm{~cm}^{4}$ \\
\hline
\end{tabular}

More extensive parametric studies have been presented in paper [7].

\section{GENERAL REMARKS AND CONCLUSIONS}

Summarizing the results of studies of the two-chord members laced in a single plane it should be stated as following:

- in both cases of bindings the more beneficial effect of equivalent second moment of area of the uniform torsion is reached $I_{\bar{T}}$ when the bindings are executed of square tubes

- the equivalent second moment of area of the analysed members laced by square tubes is about $15 \%$ larger from that laced by flat bars.

The knowledge of geometric characteristics of torsion $I_{\bar{T}} \mathrm{i} I_{\bar{\omega}}$ for two-chord members with one plane of lacings is important like in case of thin-walled open cross-section where the spatial instability (lateral-torsional buckling flexuraltorsional buckling) causes basic problems. The analysed members are sensitive to the spatial instability [14]. These members can be considered as a double-T objects in which the one plane lacing is replaced by a solid web. The equivalent double-T sections are admittedly more rigid to torsion from those fabricated by the industry but nevertheless still vulnerable to the spatial forms of buckling which has to be taken into account during the design process.

\section{REFERENCES}

1. ABAQUS 6.12 Online Documentation, Dassault Systèmes 2012.

2. ArcelorMittal: Sections and Merchant Bars. Sales Programme, 2008.

3. Biegus A.: Stalowe budynki halowe, Arkady, Warszawa 2009.

4. Bogucki W., Żyburtowicz M.: Tablice do projektowania konstrukcji metalowych, Arkady, Warszawa 2006. 
5. Gosowski B.: Problems of durability of steel in railway overhead structures, Ochrona przed Korozją, 44, 2 (2001) 40-44 (in Polish).

6. Gosowski B., Lorkowski P.: Evaluation of double-branched steel columns in a tram traction network, Przegląd Budowlany, 83, 5 (2012) 80-83 (in Polish).

7. Gosowski B., Lorkowski P., Redecki M.: Torsion stiffness of steel built-up members with lacings in one plane, Inżynieria i Budownictwo, 71, 10 (2015) 551-554 (in Polish).

8. Gosowski B.: Non-uniform torsion of stiffened open thin-walled members of steel structures, Journal of Constructional Steel Research, 63, 6 (2007) 849865.

9. Gosowski B.: Skręcanie $i$ zginanie otwartych stężonych elementów konstrukcji metalowych, Oficyna Wydawnicza Politechnika Wrocławskiej, Wrocław 2004.

10. Gosowski B., Niżniowski P.: Verification of FEM program solutions of stability and torsion problems for I shape steel members, Archives of Civil Engineering, 54, 1 (2008) 129-145.

11. Hasheela P. F.: Behaviour of single laced columns versus double laced columns, Johannesburg 2013, MSc Thesis.

12. Krzyśpiak T.: Konstrukcje stalowe hal, Arkady, Warszawa 1976.

13. Kucharczuk W., Labocha S.: Hale o konstrukcji stalowej. Poradnik projektanta, Polskie Wydawnictwo Techniczne, Rzeszów 2012.

14. Lorkowski P.: Critical load capacity of double chords steel built-up elements with a single plane laced, Raport Instytutu Budownictwa Politechniki Wrocławskiej Seria PRE nr 5/2014, PhD Thesis (in Polish).

15. Lorkowski P., Gosowski B.: Experimental investigations on non-uniform torsion of the two-chord members laced at a single plane, In: Metal Structures 2016: Proceedings of the XIII International Conference on Metal Structures (ICMS2016, Zielona Góra, Poland, 15-17 June 2016), CRC Press, 2016. p. 363-370.

16. Romanów F.: Wytrzymatość ram i nadwozi pojazdów, Wydawnictwo Komunikacji i Łączności, Warszawa 1988.

17. Rutecki J.: Cienkościenne konstrukcje nośne. Obliczenia wytrzymatościowe, PWN, Warszawa 1966.

18. Guide for the Design and Construction of Mill Buildings, AISE Technical Report No. 13, Pittsburg, Pennsylvania 2003.

19. PN-EN 1090-1+A1:2012 Wykonanie konstrukcji stalowych i aluminiowych Część 1: Zasady oceny zgodności elementów konstrukcyjnych.

20. PN-EN 1090-2+A1:2012 Wykonanie konstrukcji stalowych i aluminiowych Część 2: Wymagania techniczne dotyczące konstrukcji stalowych.

21. SOFiSTiK Manuals, SOFiSTiK AG, Oberschleißheim 2014. 
22. STATISTICA (data analysis software system), version 10, StatSoft, Inc., 2011.

\section{BADANIA NA SKRĘCANIE DWUGAŁĘZIOWYCH PRĘTÓW STALOWYCH SKRATOWANYCH W JEDNEJ PŁASZCZYŹNIE}

\section{Streszczenie}

Przedstawiono badania doświadczalne mające na celu określenie zastępczego momentu bezwładności czystego skręcania dwugałęziowych prętów stalowych z pojedynczą płaszczyzną skratowań, zlokalizowanych w osi symetrii ich przekroju poprzecznego. Pręty takie stosowane są jako słupy konstrukcji wsporczych sieci trakcyjnej a także jako słupy hal. Sztywność czystego skręcania tego typu słupów niezbędna jest do wyznaczania obciążeń krytycznych stateczności przestrzennej. Badania doświadczalnie realizowano na modelach jednoprzęsłowych prętów widełkowo podpartych na końcach, poddanych skręcaniu skupionym momentem skręcającym przyłożonym w połowie rozpiętości. W badaniach modelowych określono m.in. zależność kąta skręcenia przekroju środkowego analizowanego pręta od obciążenia momentem skręcającym. Analogiczny model pręta rozwiązano numerycznie metodą elementów skończonych za pomocą programu ABAQUS. Otrzymano przy tym dobrą zgodność wyników badań doświadczalnych i numerycznych. Zastępczy moment bezwładności czystego skręcania analizowanych prętów wyznaczono przez porównanie wyników badań doświadczalnych i numerycznych $\mathrm{z}$ wynikami otrzymanymi $\mathrm{z}$ rozwiązania odpowiedniego równania różniczkowego nieswobodnego skręcania badanego pręta, sformułowanego w ujęciu teorii Własowa. Dodatkowo wykonano analizy parametryczne podobnych elementów poddanych czystemu skręcaniu o bogatszym asortymencie przekrojów w programie SOFiSTiK. Celem tych badań było wyznaczenie praktycznych wzorów umożliwiających teoretyczne obliczenie momentu bezwładności czystego skręcania.

Słowa kluczowe: konstrukcja stalowa, elementy dwugałęziowe, elementy skratowane, pojedyncza płaszczyzna skratowań, skręcanie, badania doświadczalne i numeryczne.

Editor received the manuscript: 09.07.2016 